\title{
Immune and histopathologic responses of DNA-vaccinated hybrid striped bass Morone saxatilis $\times M$. chrysops after acute Mycobacterium marinum infection
}

\author{
David J. Pasnik ${ }^{1,2}$, Stephen A. Smith ${ }^{1, *}$ \\ ${ }^{1}$ Department of Biomedical Sciences and Pathobiology, Virginia-Maryland Regional College of Veterinary Medicine \\ (VMRCVM),Virginia-Polytechnic Institute and State University (VPI\&SU), Duck Pond Drive, Blacksburg, Virginia 24061, USA
}

${ }^{2}$ Present address: Aquatic Animal Health Research Laboratory, United States Department of Agriculture, Agricultural Research Service, Chestertown, Maryland 21620, USA

\begin{abstract}
The post-challenge immune and histopathologic responses of hybrid striped bass vaccinated with a DNA vaccine encoding the Mycobacterium marinum Ag85A gene and subsequently challenged with $M$. marinum were investigated. Juvenile hybrid striped bass Morone saxatilis $\times$ M. chrysops were injected intramuscularly with 25 or $50 \mu \mathrm{g}$ DNA plasmid and developed significant specific protective responses to live bacterial challenge $120 \mathrm{~d}$ post-vaccination. Both vaccine groups demonstrated increased survival, reduced splenic bacterial counts, and reduced granuloma formation compared to the control groups $14 \mathrm{~d}$ after challenge with approximately $8 \times 10^{5} \mathrm{cfu}$ M. marinum $\mathrm{g}^{-1}$ fish body wt. The vaccine groups also developed more rapidly and significantly increased antibody and lymphoproliferative responses post-challenge compared to control groups, and these post-challenge immune responses appear to be vital against $M$. marinum infection in vaccinated hybrid striped bass. No significant differences in immune responses were recognized between the 25 and $50 \mu \mathrm{g}$ vaccination groups, and these groups eventually experienced mortalities, splenic bacterial counts, and granuloma formation $28 \mathrm{~d}$ post-challenge comparable to those of the control groups at $14 \mathrm{~d}$ post-challenge. Therefore, vaccination of hybrid striped bass with a DNA vaccine encoding the $M$. marinum Ag85A gene provided significant but limited duration of protection against an acute high-dose M. marinum challenge.
\end{abstract}

KEY WORDS: Immunity - DNA · Vaccine - Mycobacterium marinum - Fish · Striped bass · Morone spp. Resale or republication not permitted without written consent of the publisher

\section{INTRODUCTION}

Mycobacterium marinum is well recognized as a primary agent of piscine mycobacteriosis. This bacteria was first isolated from marine fish at the Philadelphia Aquarium in 1926 and has been associated with mortalities among numerous species of fish (Aronson 1926, Austin \& Austin 1993, Chinabut 1999). After M. marinum enters the fish's body via the gastrointestinal tract, through external lesions, or by transovarian passage, mycobacterial organisms can spread throughout the body through the lymphatic or circulatory system
(Chinabut et al. 1994, Smith 1997, Chinabut 1999). These bacteria can then cause development of internal granulomas which may subsequently lead to organ malfunction or death (Austin \& Austin 1993). Mechanisms of immunity against $M$. marinum have not been completely elucidated, but previous studies indicate that protective effects in fish are based on both specific and non-specific defenses (Bartos \& Sommer 1981, Chen et al. 1996).

Protection by DNA vaccines has been largely correlated with specific immune responses to the encoded antigen. In fish, DNA vaccines have been shown to pro- 
vide protection against various piscine pathogens, such as viral hemorrhagic septicemia, infectious hematopoietic necrosis virus, hirame rhabdovirus, and channel catfish virus (Boudinot et al. 1998, Lorenzen et al. 1998, Nusbaum et al. 2002, Takano et al. 2004); protection among vaccinated fish was conferred by immunity developed to the encoded viral glycoproteins. The synthesis of antigen by DNA vaccination imitates natural infection and leads to the subsequent specific humoral and cellular responses and ultimately the generation of memory lymphocyte responses (Donnelly et al. 1997, Heppell \& Davis 2000). In mammals, DNA vaccines encoding Mycobacterium tuberculosis and $M$. bovis antigen 85A (Ag85A) have been shown to provide protection against live bacterial challenge (Denis et al. 1998, Tanghe et al. 2001). The induced protective immune responses included Ag85A-specific T-cell proliferation and cytotoxic T-cell activity. Because DNA vaccines have been shown to provide protection through specific responses, a DNA vaccine encoding the $M$. marinum Ag85A should putatively provide protection through induction via similar specific immune mechanisms.

Pasnik \& Smith (2005) determined that a Mycobacterium marinum Ag85A DNA vaccine generated significant specific immune responses against $M$. marinum through $70 \mathrm{~d}$ after vaccination. The vaccine was found to be protective when striped bass were challenged $90 \mathrm{~d}$ post-vaccination, especially in individuals injected intramuscularly (i.m.) with 25 or $50 \mu \mathrm{g}$ DNA plasmid. However, only basic post-challenge efficacy was determined in that study and mechanisms of protection were not assessed. The DNA vaccine study presented here endeavored to characterize the specific immune and histopathologic responses generated in vaccinated hybrid striped bass after live $M$. marinum challenge and to evaluate vaccine efficacy after a longer duration between vaccination and challenge. Also, because the prior study (Pasnik \& Smith 2005) was terminated $36 \mathrm{~d}$ post-challenge, the research here was designed to evaluate the protective responses of the vaccinated fish over a longer time frame after challenge. These data will provide further insight into the anti-M. marinum immune responses in hybrid striped bass, a widely cultured foodfish.

\section{MATERIALS AND METHODS}

Fish. Fingerling hybrid striped bass Morone saxatilis $\times M$. chrysops weighing approximately 40 to $50 \mathrm{~g}$ were obtained from a commercial supplier and housed at the Aquatic Medicine Laboratory of the ViginiaMaryland Regional College of Veterinary Medicine (VMRCVM) in Blacksburg, Virginia, USA. The fish $(\mathrm{n}=400)$ were maintained in multiple 22721 recircu- lation aquaculture systems with appropriate biological filtration and aeration. Water temperature was maintained at approximately 24 to $26^{\circ} \mathrm{C}$, and the fish were fed daily at 3 to $5 \%$ body weight ( $41 \%$ protein; AquaMax; Purina. Water quality parameters (ammonia, nitrite, nitrate and $\mathrm{pH}$ ) were monitored daily using a water analysis kit (HACH Co.). Care of the fish was in compliance with the guidelines of the Institutional Animal Care and Use Committee of the Virginia Polytechnic Institute and State University (VPI\&SU).

DNA construct preparation. Mycobacterium marinum (American Type Culture Collection, ATCC No. 927) was grown in Middlebrook 7 H9 broth (Difco) for $9 \mathrm{~d}$ at $28^{\circ} \mathrm{C}$. Genomic DNA was isolated from $M$. marinum based on the methods of Whipple et al. (1987) and the gene for the Ag85A $(f b p A)$ was then amplified by PCR. Ready-To-Go PCR beads (Amersham Pharmacia Biotech) were used for the PCR, and amplification was performed using an Omni Gene thermocycler (Hybaid) at $95^{\circ} \mathrm{C}$ for $5 \mathrm{~min}$, followed by 30 cycles of $1 \mathrm{~min}$ of denaturation at $95^{\circ} \mathrm{C}, 1 \mathrm{~min}$ of annealing at $60^{\circ} \mathrm{C}$, and $1 \mathrm{~min}$ of extension at $72^{\circ} \mathrm{C}$. Amplification products were analyzed on $1.5 \%$ agarose gels (Vemulapalli et al. 2002), and reaction products of the predicted size were subcloned into an expression vector, pcDNA 3.1 (Invitrogen) to create the pCMV-85A construct.

The resulting recombinant pCMV-85A plasmid was then transformed in E. coli TOP10 chemically competent cells (Invitrogen). Samples from this transformation were spread on Luria-Bertani (LB) agar plates with ampicillin $\left(100 \mu \mathrm{g} \mathrm{ml}^{-1}\right)$ and X-gal (1.6 mg) and grown overnight at $37^{\circ} \mathrm{C}$. White colonies were chosen and grown overnight at $37^{\circ} \mathrm{C}$ in $\mathrm{LB}$ broth with ampicillin $\left(100 \mu \mathrm{g} \mathrm{ml} \mathrm{m}^{-1}\right)$. Plasmids were isolated using Plasmid Maxi and Mega kits according to the manufacturers instructions (Qiagen). The DNA was then washed with $70 \%$ ethanol, dried, and resuspended in $30 \mu \mathrm{l}$ of $10 \mathrm{mM}$ Tris hydrochloride-1 mM EDTA. Clones were screened for the Mycobacterium marinum Ag85A gene by DNA sequencing (GenBank Accession No. AY225215), and final DNA concentrations in solution were determined by absorption spectrophotometry (UV-1201 spectrophotometer; Shimadzu).

Fish vaccination. Hybrid striped bass were separated into 4 experimental groups ( $\mathrm{n}=100$ each group) and given intramuscular (i.m.) injections in the hypaxial muscle. The vaccination groups consisted of fish injected with different doses of the pCMV-85A construct (25 or $50 \mu \mathrm{g}$ groups) on Days 0 and 14. As controls, other groups of fish were vaccinated with $25 \mu \mathrm{g}$ empty pcDNA 3.1 plasmid (pCMV-0 group) or sham-vaccinated with sterile phosphate-buffered saline (PBS) (Saline group). Vaccine doses were contained in $0.20 \mathrm{ml}$ of sterile PBS and injected with a $1 \mathrm{ml}$ syringe and a 27 gauge needle. 
Live bacterial challenge. On Day 120 post-vaccination, all fish from each control group (Saline and pCMV-0) and vaccination group (25 and $50 \mu \mathrm{g}$ pCMV85A) were challenged with live Mycobacterium marinum (ATCC No. 927). Fish were individually identified and arbitrarily distributed into three $568 \mathrm{l}$ tanks inside an isolation facility. Challenge was performed by i.m. injection with approximately $8 \times 10^{5} \mathrm{cfu}$ M. marinum $\mathrm{g}^{-1}$ fish body wt, a dose designed to cause onset of mortality at approximately $15 \mathrm{~d}$ (Wolf \& Smith 1999) and previously used to assess protective effects among DNA-vaccinated striped bass (Pasnik \& Smith 2005). The injection challenge route was used because it is a highly reliable and easily reproducible method and ensures challenge of all individual fish with a uniform bacterial dose (Nordmo 1997). The isolate was grown in Middlebrook $7 \mathrm{H} 9$ broth at $28^{\circ} \mathrm{C}$ for $15 \mathrm{~d}$. The resulting bacterial sample was briefly sonicated to break up bacterial aggregates, washed 3 times in PBS, resuspended in PBS, and the concentration of bacteria estimated by absorption spectrophotometry and confimed by plate counts. Fish were injected with the processed bacterial solution in the dorsal musculature just ventral to the dorsal fin. The i.m. route of administration was chosen because of its known infectivity potential, because it is a reliable and reproducible challenge method, and because i.m. injection mimics natural exposure via dermal wound invasion (Wolf \& Smith 1999, Pasnik \& Smith 2005).

During the study, morbid and dead fish were removed immediately and recorded. A relative percent survival (RPS) was determined, and this number compared the relative ability of different vaccine doses (25 $\mu \mathrm{g}$ pCMV-0, $25 \mu \mathrm{g}$ pCMV-85A, and $50 \mu \mathrm{g}$ pCMV$85 \mathrm{~A})$ to reduce mortality after live bacterial challenge.

Splenic bacterial counts. On Days 14 and 28 postchallenge (134 and 148 d post-vaccination), five fish from each unchallenged and challenged group were euthanized by tricaine methanesulfonate (MS-222; Sigma Chemical Co.) overdose and the spleen aseptically removed. A $50 \mathrm{mg}$ sample of each spleen was homogenized in $10 \mathrm{ml}$ of sterile PBS, serially diluted 1:1000, and plated on Middlebrook 7H10 agar in triplicate. Colonies of bacteria were counted after incubation for $10 \mathrm{~d}$ at $28^{\circ} \mathrm{C}$ and confirmed as Mycobacterium marinum through assessment of the morphologic characteristics (Gram-positive, acid-fast bacilli) and PCR.

Histopathologic examination of granuloma formation. Histopathologic lesions of selected internal organs were studied after challenge based on the methods of Talaat et al. (1998) and Wolf \& Smith (1999). Tissues of 5 fish from each available control and vaccination group were sampled on Days 14 and 28 post-challenge and immersed in $10 \%$ neutral buffered formalin for a period of at least $72 \mathrm{~h}$. Samples of the spleen, posterior kidney, liver, and heart were routinely processed for paraffin embedding. Tissue sections were stained with hematoxylin and eosin (H\&E) and examined by light microscopy.

Visceral granulomas in each tissue were counted and compared using 5 random $20 \times$ fields. A granuloma was defined as an aggregate of approximately 20 or more activated macrophages, with various amounts of central necrosis, peripheral fibrous connective tissue, or a base of mature lymphocytes (Wolf \& Smith 1999). A granuloma count was determined for each sampled tissue from each sampled fish; this count was then utilized to establish a mean granuloma count for each tissue from each control and vaccination group.

Immune responses of vaccinated fish after live bacterial challenge. On Day 42 post-vaccination and on Days $0,7,14,21$, and 35 post-challenge, 10 fish from each available group were anesthetized with MS-222 and blood samples taken for ELISA and lymphoproliferative assays.

ELISA. The antibody responses of fish from each group were evaluated for the presence of specific immunoglobulin against the Mycobacterium marinum Ag85A using an indirect ELISA (Vemulapalli et al. 2002, Pasnik et al. 2003). Recombinant M. marinum Ag85A was generated for the ELISA and lymphoproliferative assay as described in Pasnik \& Smith (2005). The $M$. marinum Ag85A was diluted to a $1 \mu \mathrm{g}: 50 \mu \mathrm{l}$ concentration in bicarbonate coating buffer ( $\mathrm{pH}$ 9.6) and the solution used to coat polystyrene plates (Corning) with $50 \mu \mathrm{l} \mathrm{well}{ }^{-1}$. The plates were incubated at $4^{\circ} \mathrm{C}$ overnight, washed 4 times with wash buffer (trisbuffered saline [TBS] at pH 7.4, 0.05\% Tween 20), and blocked with $2 \%$ BSA in TBS for $2 \mathrm{~h}$ at room temperature $\left(22^{\circ} \mathrm{C}\right)$. The blocking solution was then removed and diluted fish serum samples (1:100 dilution in blocking solution) were added to individual triplicate wells at $100 \mu \mathrm{l} \mathrm{well}{ }^{-1}$. A positive control serum sample and a diluent- only sample were tested in the same manner. The plates were incubated for $4 \mathrm{~h}$ at room temperature and then washed 4 times with wash buffer.

The secondary antibody solution, a protein A-peroxidase conjugate (Sigma), was added at $100 \mu$ well $^{-1}$ at a 1:500 dilution. After $1 \mathrm{~h}$ incubation at room temperature, the plates were washed 4 times and $100 \mu \mathrm{l}$ of substrate solution (TMB Microwell Peroxidase Substrate; Kirkegaard and Perry Laboratories) were added to each well. After $20 \mathrm{~min}$ incubation at room temperature, $100 \mu \mathrm{l}$ of stop solution ( $0.185 \mathrm{M}$ sulfuric acid) were added. The absorbance at $450 \mathrm{~nm}$ was then recorded with a microplate reader (Molecular Devices) and the mean absorbance of each sample serum compared against that of the control well.

Lymphoproliferative assay. Peripheral blood lymphocytes of fish from each group were evaluated for the 
presence of specific immunoglobulin against ConA and against Mycobacterium marinum Ag85A using a lymphoproliferative assay (Marsden et al. 1996, Pasnik et al. 2003). Blood from fish in each control and vaccination group was collected and diluted with sterile RPMI-1640 medium (Mediatech, Cellgro). The resulting cell suspension was washed twice in RPMI-1640 medium and resuspended in $3 \mathrm{ml}$ RPMI-1640 medium. Using an aseptic technique, phagocytes were placed over the Lymphoprep separation medium (1.077; Nycomed) and centrifuged at $400 \times g$. The buffy coat layer was collected and washed twice in cold RPMI-1640 medium, resuspended in $3 \mathrm{ml}$ medium, and enumerated and size-analyzed with a CASY 1 Model TTC cell counter and analyzer system (Scharfe System). The cells were then adjusted to $1 \times 10^{6}$ cells ml $^{-1}$ with RPMI-1640 medium supplemented with $2 \mathrm{mM}$ L-glutamine, $10 \%$ heat-inactivated fetal bovine serum (Sigma), $50 \mathrm{IU} \mathrm{ml}^{-1}$ penicillin, and $50 \mathrm{mg} \mathrm{ml}^{-1}$ streptomycin (Cellgro). Aliquots of cells were cultured in triplicate in 96-well plates (Corning) with supplemented RPMI-1640 medium containing $1.0 \mu \mathrm{g}$ M. marinum Ag85A, $1.25 \mu \mathrm{g}$ ConA (positive control) (Sigma), or no additives (negative control) (Ahmed et al. 1994, Gogal et al. 1999, Vemulapalli et al. 2002). The cells were cultured at $28^{\circ} \mathrm{C}$ in $5 \% \mathrm{CO}_{2}$ for $24 \mathrm{~h}$. After $24 \mathrm{~h}, 20 \mu \mathrm{l}$ Alamar Blue (Trek Diagnostic) was added to the wells, and the cells were incubated for an additional $48 \mathrm{~h}$. Absorbance was then measured at 570 and $600 \mathrm{~nm}$ with a kinetic microplate reader (Molecular Devices), and specific absorbance of the unstimulated cells (negative control) was subtracted from the specific absorbance of the cells to yield a delta-specific absorbance.

Statistical analysis. Statistical analysis was performed with SAS software (SAS Institute). Splenic bacterial count data was subjected to pairwise comparisons using the log-rank test, and the results were Bonferroni-corrected for the number of comparisons. The ELISA data was subjected to a mixed-model repeatedmeasures analysis of variance, while the lymphocyte proliferation was subjected to a 1-way analysis of variance; Bonferroni correction was performed to compare the various experimental dose groups within each sampling day. The data for each test is reported as means with SEM determined from pooled means. An overall significance level of $p<0.05$ was accepted.

\section{RESULTS}

\section{Protective effects following live bacterial challenge}

Vaccinated fish were exposed to live Mycobacterium marinum at a dose designed to cause the onset of mortality at approximately $15 \mathrm{~d}$ post-challenge. When fish were challenged $120 \mathrm{~d}$ post-vaccination, the Saline control and pCMV-0 group fish experienced onset of mortalities early in the experiment, reaching $100 \%$ mortality within $21 \mathrm{~d}$ (Fig. 1). In contrast, the 25 and $50 \mu \mathrm{g}$ groups showed a delayed onset of mortality, with the first mortalities occurring on Days 22 and 21 postchallenge, respectively. The vaccination groups also exhibited a significantly increased mean survival time (Table 1), although all of the fish in the vaccination groups eventually died within $46 \mathrm{~d}$. After the first mortalities in each group, all groups experienced a fairly rapid progression of disease to $100 \%$ mortality. However, while all the fish in the control groups died within approximately $15 \mathrm{~d}$ of the onset of mortalities, those in the vaccinated groups died within approximately $25 \mathrm{~d}$ of the first mortalities.

Splenic bacterial cultures were obtained on Days 14 and 28 post-challenge and incubated for $10 \mathrm{~d}$. Colonies present after incubation were identified as Mycobacterium marinum through assessment of morphologic characteristics and PCR. On Day 14 post-challenge, both control groups exhibited significantly higher mycobacterial growth in the spleen samples than either the 25 or $50 \mu \mathrm{g}$ pCMV-85A groups. The RPS on Day 14 post-challenge for the pCMV-0 group was $0 \%$, while the RPS values for the vaccination groups were $100 \%$ each. Later, the RPS on Day 28 post-challenge showed vaccine efficacies for the 25 and $50 \mu \mathrm{g}$ groups of 91 and $88 \%$, respectively, compared to $0 \%$ for the other group (Table 2). On Day 28 post-challenge, splenic samples from the 25 and $50 \mu \mathrm{g}$ groups also indicated increased growth of bacteria within the fish, although these bacterial counts were still not as high as the bacterial counts from the control groups on Day 14 post-challenge.

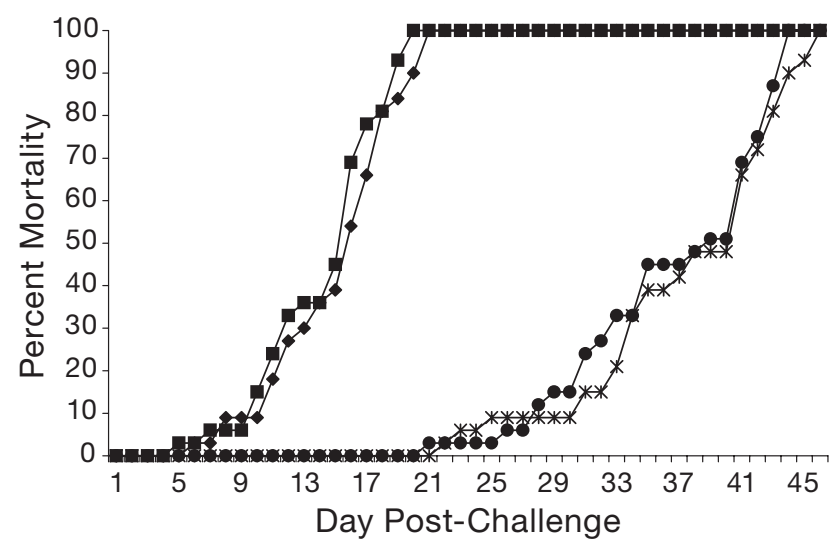

Fig. 1. Morone saxatilis $\times$ M. chrysops challenged by $М y c o-$ bacterium marinum. Cumulative mortality for pCMV-85Avaccinated, hybrid striped bass, following challenge with approx. $8 \times 10^{5} \mathrm{cfu}$ M. marinum $\mathrm{g}^{-1}$ fish body wt on Day 120 post-vaccination. $(\bullet)$ Saline control; (匹) pCMV-0 control;

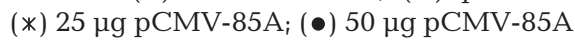


Table 1. Morone saxatilis $\times M$. chrysops challenged by Mycobacterium marinum. Comparison of mean survival time, relative percent survival (RPS) and splenic bacterial counts (log M. marinum, cfu) on Day 14 post-challenge following live bacterial challenge of pCMV-85A-vaccinated hybrid striped bass. Data are mean \pm SEM. Different superscripts indicate significant differences $(\mathrm{p}<0.05)$ between groups within each measured category determined according to Bonferroni-corrected data. RPS = $(1-\%$ mortality vaccinated fish $/ \%$ mortality Saline control fish) $\times 100$. na: not applicable

\begin{tabular}{|lccc|}
\hline $\begin{array}{l}\text { Vaccination } \\
\text { group }\end{array}$ & $\begin{array}{l}\text { Survival } \\
\text { time (d) }\end{array}$ & Log M. marinum (cfu) & $\begin{array}{c}\text { RPS } \\
(\%)\end{array}$ \\
\hline $\begin{array}{l}\text { Controls } \\
\text { Saline }\end{array}$ & $15.3 \pm 0.68^{\mathrm{a}}$ & $5.0690 \pm 0.09732^{\mathrm{a}}$ & na \\
pCMV-0 & $14.6 \pm 0.65^{\mathrm{a}}$ & $5.1495 \pm 0.09732^{\mathrm{a}}$ & 0 \\
pCMV-85A & & & \\
$25 \mu \mathrm{g}$ & $37.7 \pm 1.12^{\mathrm{b}}$ & $3.8122 \pm 0.09732^{\mathrm{b}}$ & 100 \\
$50 \mu \mathrm{g}$ & $36.9 \pm 1.09^{\mathrm{b}}$ & $3.8215 \pm 0.09732^{\mathrm{b}}$ & 100 \\
\hline
\end{tabular}

The histopathology of the challenged fish indicated rapidly progressing granuloma formation in the control fish. The inflammatory reaction was characterized by formation of discrete non-necrotizing and necrotizing granulomas with associated macrophages, lymphocytes, bacteria, and connective tissue. When fish were examined on Day 14 post-challenge, the control groups exhibited significant numbers of granulomas within the spleen, posterior kidney, liver, and heart (Table 3). The spleens of the control groups were most affected, and mean splenic granuloma counts for the Saline and pCMV-0 groups were 13.6 and 15.2, respectively. Furthermore, the numerous splenic granulomas almost obliterated the normal tissue architecture. The splenic tissues of the 25 and $50 \mu \mathrm{g}$ groups exhibited only a low number of granulomas and appeared largely unaffected; mean splenic scores for the 25 and $50 \mu \mathrm{g}$ groups were 1.0

Table 2. Morone saxatilis $\times$ M. chrysops challenged by Mycobacterium marinum. Comparison of mean survival time, relative percent survival (RPS) and splenic bacterial counts (log M. marinum, cfu) on Day 28 post-challenge following live bacterial challenge of pCMV-85A-vaccinated hybrid striped bass. No significant differences $(p<0.05)$ between vaccination groups within each measured category were found according to Bonferroni-corrected data. Data presentation as in Table 1

\begin{tabular}{|lrcc|}
\hline $\begin{array}{l}\text { Vaccination } \\
\text { group }^{\text {a }}\end{array}$ & $\begin{array}{l}\text { Survival } \\
\text { time (d) }\end{array}$ & Log M. marinum (cfu) & $\begin{array}{r}\text { RPS } \\
(\%)\end{array}$ \\
\hline $25 \mu \mathrm{g}$ & $37.7 \pm 1.12$ & $4.7227 \pm 0.05385$ & 91 \\
$50 \mu \mathrm{g}$ & $36.9 \pm 1.09$ & $4.6709 \pm 0.05385$ & 88 \\
\multicolumn{4}{|l}{ all fish in Saline and pCMV-0 control groups were dead } \\
by Day 28 post-challenge and are thus not included
\end{tabular}

and 0.3, respectively, and were significantly lower than those of the control groups. However, on Day 28 post-challenge, the 25 and $50 \mu \mathrm{g}$ groups had developed numerous granulomas, with mean granuloma counts of all sampled tissues approaching the granuloma counts of the control groups on Day 14 postchallenge.

\section{Ag85A-specific antibody production}

The concentration of Mycobacterium marinum Ag85A-specific antibodies were measured by ELISA post-vaccination and post-challenge. On Day 42 postvaccination, the control groups exhibited low concentrations of specific antibodies (Saline $=0.005 \pm 0.011$; pCMV-0 $=0.011 \pm 0.011$ ). Meanwhile, the vaccination groups showed significantly increased levels of antibodies $(25 \mu \mathrm{g}$ group $=0.469 \pm 0.011 ; 50 \mu \mathrm{g}$ group $=$ $0.487 \pm 0.011$ ). On Day 0 post-challenge (Day 120 post-vaccination), negligible levels of specific antibodies were detected in all pCMV-85A-vaccinated fish (Fig. 2). However, rapidly increasing concentrations of antibodies were generated by the vaccination groups up to Day 28 post-challenge. Significantly

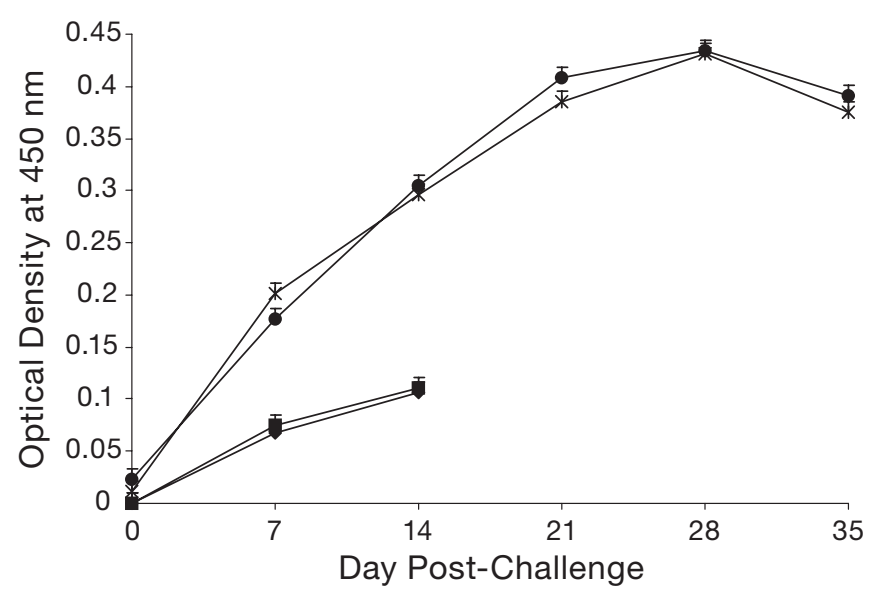

Fig. 2. Morone saxatilis $\times$ M. chrysops challenged by Mycobacterium marinum. Detection of Ag85A-specific antibodies by ELISA from serum of pCMV-85A-vaccinated, M. marinumchallenged hybrid striped bass. Sera were collected from available vaccine groups on Days $0,7,14,21,28$, and 35 post-challenge, diluted 1:100, and assayed for presence of antibodies to $M$. marinum Ag85A using absorption spectrophotometry. ( $\bullet$ Saline control; (匹) pCMV-0 control; (*) $25 \mu \mathrm{g}$ pCMV-85A $A_{i} \bullet 50 \mu \mathrm{g}$ pCMV-85A. Both control groups experienced expected $100 \%$ mortalities during experiment and thus samples were not available for all time points. Data are mean + SEM of $\mathrm{OD}_{450}$ of developed color. pCMV-85A vaccination groups were significantly different $(p<0.05)$ from the control groups at all time points after Day 0 post-challenge, but no significant differences were noted between the 25 and $50 \mu \mathrm{g}$ groups at any time point 
Table 3. Morone saxatilis $\times$ M. chrysops challenged by Mycobacterium marinum. Comparison of mean granuloma counts following live bacterial challenge of pCMV-85A-vaccinated hybrid striped bass. Day p-c: day post-challenge. ${ }^{*}$ Significant differences $(p<0.05)$ between groups and Saline control indicated for each sampled internal organ; mean granuloma counts for vaccination groups on Day 28 were compared to those of the Saline control group on Day 14

\begin{tabular}{|c|c|c|c|c|c|}
\hline $\begin{array}{l}\text { Vaccination } \\
\text { group }^{\mathrm{a}}\end{array}$ & $\begin{array}{r}\text { Day } \\
\text { p-c }\end{array}$ & Spleen & $\begin{array}{l}\text { Posterior } \\
\text { kidney }\end{array}$ & Liver & Heart \\
\hline \multicolumn{6}{|l|}{ Controls } \\
\hline Saline & 14 & 13.6 & 4.2 & 2.6 & 4.2 \\
\hline pCMV-0 & 14 & 15.2 & 5.1 & 2.4 & 4.5 \\
\hline \multicolumn{6}{|l|}{ pCMV-85A } \\
\hline $25 \mu \mathrm{g}$ & 14 & $1^{*}$ & $0.1^{*}$ & $0^{*}$ & $0^{*}$ \\
\hline $50 \mu \mathrm{g}$ & 14 & $0.3^{*}$ & $0^{*}$ & $0^{*}$ & $0^{*}$ \\
\hline $25 \mu \mathrm{g}$ & 28 & 12 & $2.5^{*}$ & 1.7 & $0.2^{*}$ \\
\hline $50 \mu \mathrm{g}$ & 28 & 12.6 & 4 & 1.6 & 2.1 \\
\hline
\end{tabular}

greater responses were seen among the vaccination groups than the control groups, although there were no significant differences between the 2 vaccination groups. After Day 28 post-challenge, the concentrations of antibodies began to decrease, but the fish continued to maintain significantly elevated levels of antibodies. Specific antibody responses were detected in the Saline and pCMV-0 and groups after challenge, although these specific responses were minimal and increased slowly.

\section{Lymphoproliferative responses}

Post-vaccination and post-challenge samples of peripheral lymphocytes were cultured in vitro in the presence of ConA or Ag85A. On Day 42 post-vaccination, ConA-stimulated cells from the vaccination groups $(25 \mu \mathrm{g}$ group $=0.504 \pm 0.018 ; 50 \mu \mathrm{g}$ group $=$ $0.538 \pm 0.018$ ) demonstrated significantly increased proliferation compared to those of the control groups (Saline $=0.372 \pm 0.018 ; \mathrm{pCMV}-0=0.332 \pm 0.018$ ). This significant difference was largely diminished on Day 0 post-challenge (Day 120 post-vaccination). After live bacterial challenge, all groups still exhibited proliferative lymphocyte responses after ConA stimulation (Fig. 3). However, the 25 and $50 \mu \mathrm{g}$ groups demonstrated significant responses above those of the control groups, and these responses continued to increase after the controls had experienced the expected $100 \%$ mortalities.

On Day 42 post-vaccination, Ag85A-stimulated cells from the vaccination groups $(25 \mu \mathrm{g}$ group $=0.368 \pm$ $0.012 ; 50 \mu \mathrm{g}$ group $=0.431 \pm 0.012$ ) showed significantly increased proliferation above those of the control groups (Saline $=0.001 \pm 0.012$; pCMV-0 $=0.002 \pm 0.012$ ). This significant difference was largely diminished on Day 0 post-challenge (Day 120 post-vaccination). Following live bacterial challenge, significantly increased lymphoproliferative responses were once again detected among the vaccination groups on Day 7 post-challenge (Fig. 4). Both the 25 and $50 \mu \mathrm{g}$ groups demonstrated significant lymphocyte responses that continued to rapidly increase until Day 21 post-vaccination. Minimal antigen-specific lymphoproliferative responses were detected in the Saline and pCMV-0 control groups after challenge with M. marinum.

\section{DISCUSSION}

Prior experiments have indicated that a vaccine with the Mycobacterium marinum Ag85A can provide protection against $M$. marinum infection in striped bass, but only the post-vaccination, pre-challenge immunostimulatory effects were studied (Pasnik et al. 2003, Pasnik \& Smith 2005). The study presented herein characterizes the immune mechanisms involved in protection against $M$. marinum after challenge and indicates the importance of Ag85A-specific immune responses generated post-challenge. Vaccinated fish (25 and $50 \mu \mathrm{g}$ groups) exhibited very low

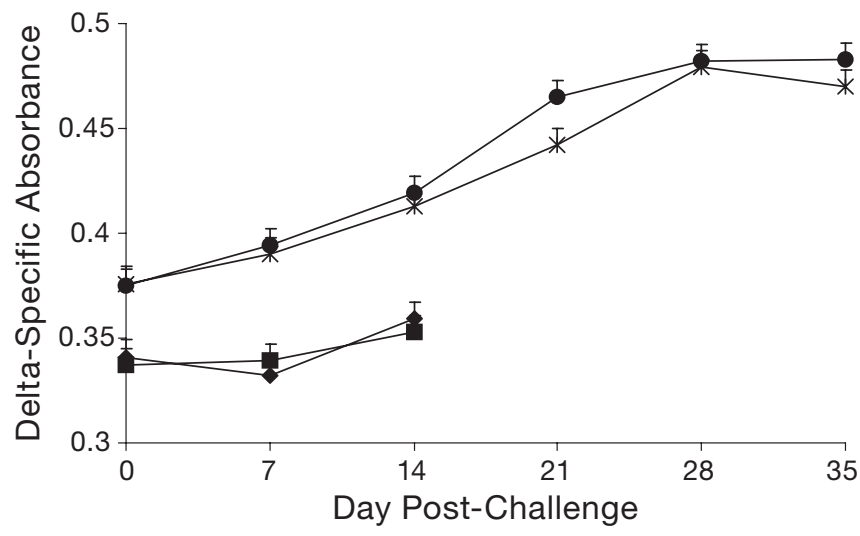

Fig. 3. Morone saxatilis $\times M$. chrysops challenged by Mycobacterium marinum. Proliferation of peripheral lymphocytes from pCMV-85A-vaccinated, M. marinum-challenged hybrid striped bass after in vitro stimulation with ConA. Cells were harvested from available vaccine groups on Days $0,7,14,21$, 28 and 35 post-challenge, cultured for $3 \mathrm{~d}$, and lymphocyte proliferation determined by Alamar blue assay. Data are mean + SEM of the delta-specific absorbance of the developed color. Symbols and further details as in Fig. 2 


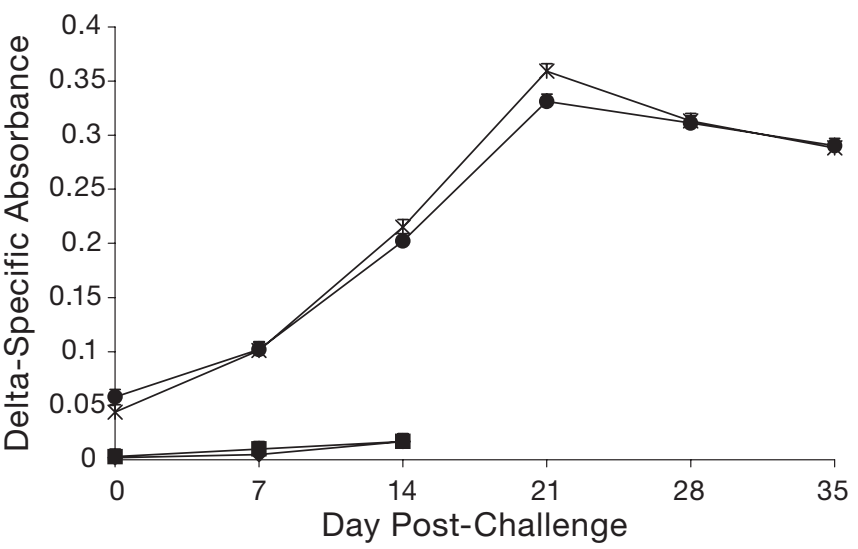

Fig. 4. Morone saxatilis $\times M$. chrysops challenged by Mycobacterium marinum. Proliferation of peripheral lymphocytes from pCMV-85A-vaccinated, $M$. marinum-challenged hybrid striped bass after in vitro stimulation with Ag85A. Symbols and further details as in Figs. 2 \& 3

levels of specific responses at Day 0 post-challenge (Day 120 post-vaccination), suggesting that vaccine efficacy was not conferred by pre-existing elevated levels of immune responses induced by vaccination. Instead, the protective effects were most probably conferred by immunologic memory and the rapidly increasing specific immune responses following challenge. These post-challenge immune responses included rapidly increasing specific antibody concentrations and lymphocyte responsiveness. These immune responses appear to be vital against $M$. marinum infection in hybrid striped bass. In contrast, the control groups (Saline and pCMV-0 groups) exhibited only minimal, slowly-increasing specific responses, which themselves were putatively generated by the $M$. marinum challenge. Furthermore, only a slight increase in control group non-specific lymphocyte stimulation was noted after ConA treatment, and no protective effects were demonstrated among the control groups.

Mortality patterns post-challenge indicated protection based on delayed onset of mortalities and increased relative percent survival among the 25 and $50 \mu \mathrm{g}$ groups. By Day 21 post-challenge, both control groups had reached $100 \%$ mortalities, while mortalities among the vaccine groups were 0 to $3 \%$. However, in contrast to our previous study in which striped bass were challenged $90 \mathrm{~d}$ post-vaccination (Pasnik \& Smith 2005), the protective effects in this study were diminished, although still significant, $35 \mathrm{~d}$ after challenge on Day 120 post-vaccination. In the present study, the 25 and $50 \mu \mathrm{g}$ groups showed relative percent survival of 61 and $55 \%$, respectively, $35 \mathrm{~d}$ after challenge. These findings indicate a significant, but limited protective effect of the DNA vaccine.
Previous studies by other researchers have shown protective effects in fish following DNA vaccine administration. DNA vaccines for viral piscine pathogens have been well examined and indicate that plasmid constructs encoding certain antigens are capable of inducing significant numbers of virus-neutralizing antibodies and reducing mortalities among vaccinated fish populations after live viral challenge (Boudinot et al. 1998, Lorenzen et al. 1998, Nusbaum et al. 2002, Takano et al. 2004). Some of these studies have also shown that the efficacy of a DNA vaccine depends on the utilized encoded antigen. For example, Anderson et al. (1996) determined that a DNA vaccine encoding the infectious hematopoietic necrosis virus (IHNV) nucleoprotein was not immunostimulatory or protective in rainbow trout; however, the vaccine construct encoding the IHNV glycoprotein conferred significant protection against live IHNV challenge. DNA vaccines against bacterial piscine pathogens have not been largely examined, although Gomez-Chiarri et al. (1996) were able to generate significant protection with DNA vaccines against Renibacterium salmoninarum. While these studies offer promising results, most have not assessed the long-term efficacy and the post-challenge protective immune response provided by these DNA vaccines.

Our previous work found that a recombinant vaccine expressing a mammalian Mycobacterium sp. Ag85A was significantly immunostimulatory in Morone sp. post-vaccination, pre-challenge (Pasnik et al. 2003). However, no protective effects were conferred when fish were challenged with a high dose of Mycobacterium marinum. In the Pasnik \& Smith (2005) study and the present study, significant protection was most probably conferred by the utilization of a DNA vaccine as the method of delivery for the M. marinum Ag85A. These factors putatively identify sufficiently primed, immune responses that were significantly stimulated post-challenge to provide protection. In addition, the vaccine was protective even although Morone spp. are highly susceptible to disease caused by Mycobacterium spp. (Wolf \& Smith 1999, Gauthier et al. 2003, Harms et al. 2003). The data from the present study nonetheless suggests that the vaccine only delays the pathogenesis of the disease. This conclusion was supported by the splenic bacterial counts and histopathology evaluations. On Day 14 post-challenge, splenic bacterial counts for the vaccination groups were significantly lower than the counts for the control groups. Futhermore, tissue samples from this time point indicated a clear difference in mean granuloma counts between the vaccination and the control groups. The bacterial counts and degree of granulomatous inflammation roughly corresponded to the percent mortalities among the groups; the Saline and pCMV-0 groups 
exhibited high splenic bacterial growth, significant lesion development and increased mortalities, while the vaccination groups had low bacterial growth, minimal lesion development and $0 \%$ mortalities. However, at Day 28 post-challenge, samples of the vaccination groups exhibited bacterial growth and lesions similar in magnitude and severity to those of the control groups at Day 14 post-challenge. Although the 25 and $50 \mu \mathrm{g}$ groups had only 9 to $12 \%$ mortalities $28 \mathrm{~d}$ postchallenge, the increasing bacterial counts and developing granulomas could account for the subsequent increase in mortalities.

The high-challenge i.m. dose of $8 \times 10^{5} \mathrm{cfu}$ Mycobacterium marinum $\mathrm{g}^{-1}$ fish body wt was designed to cause acute mortalities among naïve striped bass (Wolf \& Smith 1999, Pasnik \& Smith 2005). The post-challenge immune responses in vaccinated individuals may hinder the immediate dissemination and/or replication of $M$. marinum in the host. However, these postchallenge responses only appear to delay development of clinical signs and mortalities instead of preventing the disease. Long-term immunity to the administered M. marinum may have been deterred by immunosuppression of the fish through the use of an unnaturally high bacterial challenge dose and/or induction of an unsuitable immune response. The high $M$. marinum dose, presumably overwhelmed the induced immune responses or immunosuppressed the vaccinated fish, eventually allowing unhindered disease development. Mycobacterium spp. themselves are known to be immunosuppressive (Geijtenbeek et al. 2003) and to resist host immune activity (Chan et al. 2002, Ruley et al. 2004), thereby encumbering immunity. Immunosuppression and/or induction of inappropriate immune responses are important factors in the development of piscine mycobacteriosis (Barker et al. 1997, Talaat et al. 1998, Gauthier et al. 2003, Harms et al. 2003). Based upon the post-challenge ELISA and lymphoproliferative assays, the decrease in vaccinated fish immunity occurred after the measured immune response peaks at 21 to $28 \mathrm{~d}$ post-challenge. The subsequent decreases in immune responses coincided with the onset of mortalities among vaccinated fish.

These factors may have prevented long-term vaccine-induced protection against the experimental high-dose exposures and allowed the eventual development of $100 \%$ mortality in the vaccination groups. However, in nature, the fish would most likely be naturally exposed to mycobacterial organisms at significantly lower levels, and would not naturally experience high-dose exposure by direct mycobacterial i.m. injection. As such, the vaccine produced as a result of this research may confer better protective effects against natural routes of infection (i.e. ingestion, penetration of intact mucus membranes, or dermal wound invasion) by inducing post-vaccination or post-challenge immune responses capable of controlling environmentally relevant numbers of mycobacteria.

Acknowledgements. The authors thank Mr. D. Ward for statistical assistance with this study. This research was supported by USDA Animal Health and Disease Grant No.1-39095.

\section{LITERATURE CITED}

Ahmed SA, Gogal Jr. RM, Walsh JE (1994) A new rapid and simple non-radioactive assay to monitor and determine the proliferation of lymphocytes: an alternative to $\left[{ }^{3} \mathrm{H}\right]$ thymidine incorporation assay. J Immunol Methods 170:211-224

Anderson ED, Mourich DV, Fahrenkrug S, LaPatra S, Shepherd J, Leong JC (1996) Genetic immunization of rainbow trout (Oncorhynchus mykiss) against infectious hematopoietic necrosis virus. Mol Mar Biol Biotechnol 5:114-122

Aronson JD (1926) Spontaneous tuberculosis in salt water fish. J Infect Dis 39:315-320

Austin B, Austin DA (1993) Mycobacterium spp. In: Austin B, Austin DA (eds) Bacterial fish pathogens: disease in farmed and wild fish. Ellis Horwood, New York, p 45-50

Barker LP, George KM, Falkow S, Small PLC (1997) Differential trafficking of live and dead Mycobacterium marinum organisms in macrophages. Infect Immun 65:1497-1504

Bartos JM, Sommer CV (1981) In vivo cell mediated immune response to $M$. tuberculosis and $M$. salmoniphilum in rainbow trout (Salmo gairdneri). Dev Comp Immunol 5:75-83

Boudinot P, Blanco M, de Kinkelin P, Benmansour A (1998) Combined DNA immunization with the glycoprotein gene of viral hemorrhagic septicemia virus and infectious hematopoietic necrosis virus induces double-specific protective immunity and nonspecific response in rainbow trout. Virology 249:297-306

Center for Veterinary Medicine (2000) Drugs approved for use in aquaculture (poikilothermic food species). Federal Drug Administration. Available at www.fda.gov/cvm/ index/aquaculture/appendixa6.htm

Chan K, Knaak T, Satkamp L, Humbert O, Falkow S, Ramakrishnan L (2002) Complex pattern of Mycobacterium marinum gene expression during long-term granulomatous infection. Proc Natl Acad Sci USA 99:3920-3925

Chen SC, Yoshida T, Adams A, Thompson KD, Richards RH (1996) Immune response of rainbow trout to extracellular products of Mycobacterium spp. J Aquat Anim Health 8:216-222

Chinabut S (1999) Mycobacteriosis and nocardiosis. In: Woo PTK, Bruno DW (eds) Fish diseases and disorders: viral, bacterial and fungal infections. CAB International, New York, p 319-340

Chinabut S, Kanayati Y, Pungkachonboon T (1994) Study of transovarian transmission of mycobacteria in Betta splendens Regan. In: Chou LM, Munro AD, Lam TJ, Chen TW and 7 others (eds) Proceedings of the Third Asian Fisheries Forum. Asian Fisheries Society, Manila, p 84-85

Denis O, Tanghe A, Palfliet K, Jurion F and 7 others (1998) Vaccination with plasmid DNA encoding mycobacterial antigen 85A stimulates CD4+ and CD8+ T-cell epitopic repertoire broader than that stimulated by Mycobacterium tuberculosis H37Rv infection. Infect Immun 66:1527-1533

Donnelly JJ, Ulmer JB, Shiver JW, Liu MA (1997) DNA vaccines. Annu Rev Immunol 15:617-648 
Gauthier DT, Rhodes MW, Vogelbein WK, Kator H, Ottinger CA (2003) Experimental mycobacteriosis in striped bass Morone saxatilis. Dis Aquat Org 54:105-117

Geijtenbeek TB, van Vliet SJ, Koppel EA, Sanchez-Hernandez M, Vandenbroucke-Grauls CM, Appelmelk B, van Kooyk Y (2003) Mycobacteria target DC-SIGN to suppress dendritic cell function. J Exp Med 197:7-17

Gogal RM Jr., Smith BJ, Robertson JL, Smith SA, Holladay SD (1999) Tilapia (Oreochromis niloticus) dosed with azathioprine display immune effects similar to those seen in mammals, including apoptosis. Vet Immunol Immunopathol 68:209-227

Gomez-Chiarri M, Brown LL, Levine RP (1996) Protection against Renibacterium salmoninarum infection by DNAbased immunization. In: Donaldson EM, MacKinlay DD (eds) Aquaculture biotechnology symposium proceedings, International Congress on the Biology of Fishes. American Fisheries Society, Bethesda, MD, p 155-157

Harms CA, Howard KE, Wolf JC, Smith SA, KennedyStoskopf S (2003) Transforming growth factor-response to mycobacterial infection in striped bass Morone saxatilis and hybrid tilapia Oreochromis spp. Vet Immunol Immunopathol 95:155-163

Heppell J, Davis HL (2000) Application of DNA vaccine technology to aquaculture. Adv Drug Delivery Rev 43:29-43

Kanellos T, Sylvester ID, Ambali AG, Howard CR, Russell PH (1999) The safety and longevity of DNA vaccines for fish. Immunology 96:307-313

Lorenzen N, Lorenzen E, Einer-Jensen K, Heppell J, Wu T, Davis H (1998) Protective immunity to VHS in rainbow trout (Oncorhynchus mykiss, Walbaum) following DNA vaccination. Fish Shellfish Immunol 8:261-270

Marsden MJ, Vaughan LM, Foster TJ, Secombes CJ (1996) A live (delta aroA) Aeromonas salmonicida vaccine for furunculosis preferentially stimulates T-cell responses relative to B-cell responses in rainbow trout (Oncorhynchus mykiss). Infect Immun 64:3863-3869

Nordmo R (1997) Strengths and weaknesses of different challenge methods. In: Gudding R, Lillehaug A, Midtlying PJ, Brown F (eds) Fish vaccinology: developments in biological standardization, Vol 90. Karger, Basel, p 303-309

Nusbaum KE, Smith BF, DeInnocentes P, Bird RC (2002) Protective immunity induced by DNA vaccination of channel catfish with early and late transcripts of the

Editorial responsibility: Donald Evans, Athens, Georgia, USA channel catfish herpesvirus (IHV-1). Vet Immunol Immunopathol 84:151-168

Pasnik DJ, Smith SA (2005) Immunostimulatory and protective effects of a DNA vaccine for Mycobacterium marinum. Vet Immunol Immunopathol 103:195-206

Pasnik DJ, Vemulapalli R, Smith SA, Schurig GG (2003) A recombinant vaccine expressing a mammalian $\mathrm{Myco}-$ bacterium sp. antigen is immunostimulatory but not protective in striped bass. Vet Immunol Immunopathol 95: $43-52$

Ruley KM, Ansede JH, Pritchett CL, Talaat AM, Reimschuessel R, Trucksis M (2004) Identification of Mycobacterium marinum virulence genes using signature-tagged mutagenesis and the goldfish model of mycobacterial pathogenesis. FEMS Microbiol Lett 232:75-81

Smith SA (1997) Mycobacterial infections in pet fish. Semin Avian Exot Pet 6:40-45

Takano T, Iwahori A, Hirono I, Aoki T (2004) Development of a DNA vaccine against hirame rhadovirus and analysis of the expression of immune-related genes after vaccination. Fish Shellfish Immunol 17:367-374

Talaat AM, Reimschuessel R, Wasserman SS, Trucksis M (1998) Goldfish, Carassius auratus, a novel animal model for the study of Mycobacterium marinum pathogenesis. Infect Immun 66:2938-2942

Tanghe A, Denis O, Lambrecht B, Motte V, van den Berg T, Huygen K (2000) Tuberculosis DNA vaccine encoding Ag85A is immunogenic and protective when administered by intramuscular needle injection but not by epidermal gene gun bombardment. Infect Immun 68: 3854-3860

Vemulapalli R, He Y, Sriranganathan N, Boyle SM, Schurig GG (2002) Brucella abortus RB51: enhancing vaccine efficacy and developing multivalent vaccines. Vet Microbiol 90:521-532

Whipple DL, LeFebvre RB, Andrews RE, Thiermann AB (1987) Isolation and analysis of restriction endonuclease digestive patterns of chromosomal DNA from Мycobacterium paratuberculosis and other Mycobacterium species. J Clin Microbiol 25:1511-1515

Wolf JC, Smith SA (1999) Comparative severity of experimentally induced mycobacteriosis in striped bass Morone saxatilis and hybrid tilapia Oreochromis spp. Dis Aquat Org 38:191-200

Submitted: June 3, 2005; Accepted: December 9, 2005

Proofs received from author(s): November 1, 2006 